\title{
Rapid Separation of Isobutene from Butene- 1 by Gas Chromatography
}

\section{W. Kladnig}

Institut für Physikalische Chemie, Technische Hochschule Wien, Austria

The separation of isobutene from butene- 1 by gas-liquidchromatography (GLC) was a problem which had not been solved satisfactorily*. Since many stationary liquids like dimethylsulfolane, acetonylacetone, tetraisobutylene, dinonylphthalate or bis-2-methoxyethyladipate- di-2-ethylhexylsebacate and others are useful for separating linear butenes, i. e. butene-1, cis-butene-2, trans-butene- 2 in a reasonable time, separation of isobutene from butene- 1 seemed to need unusually long columns and very long retention times. For instance Bober [1] describes a separation of isobutene from butene- 1 over $30 \%$ dimethylsulfolane on Firebrick $42 / 60$ mesh with a $15.6 \mathrm{~m}\left(1 / 4^{\prime \prime}\right)$ column at $0{ }^{\circ} \mathrm{C}$ with a retention time of about 48 minutes for isobutene. Leibrand [2] mentions $11 \% \mathrm{AgNO}_{3}+29 \%$ benzyl cyanide on Chromosorb P 80/100 mesh, column: $9 \mathrm{~m} \mathrm{x} 1 / 8^{\prime \prime}$ at $20^{\circ} \mathrm{C}$ in about 25 minutes for isobutene. Die thyleneglycol $+\mathrm{AgNO}_{3}$ is often used for this separation, but columns with this stationary phase are notorious for their temperature sensitivity and short life (bleeding).

The following method describes a separation of isobutene from butene- 1 in a few minutes using propylenecarbonate as the stationary phase, which may be useful for technical application (routine analysis). Column: stainless steel; length: $8 \mathrm{~m} ; 1 / 8^{\prime \prime}$. Stationary phase: $20 \%$ Propylenecarbonate; Support: Chromosorb P-AW 60/80 mesh. Carrier gas: nitrogen; flow: $30 \mathrm{~cm}^{3} / \mathrm{min}$ Pressure: 22 psi

Temperature: $0{ }^{\circ} \mathrm{C}$

Detector: FID

Preparation of the column material was carried out in chloroform at $30^{\circ} \mathrm{C}$ following the method of $R$. Kaiser [3].

The separation of isobutene from butene-1 is shown in Fig. 1. Retention times:

butene-1: $\quad 6 \min 18 \mathrm{~s}$

isobutene: $\quad 6 \min 49 \mathrm{~s}$

trans-butene-2: $7 \min 37 \mathrm{~s}$

cis-butene-2: $\quad 8 \min 55 \mathrm{~s}$

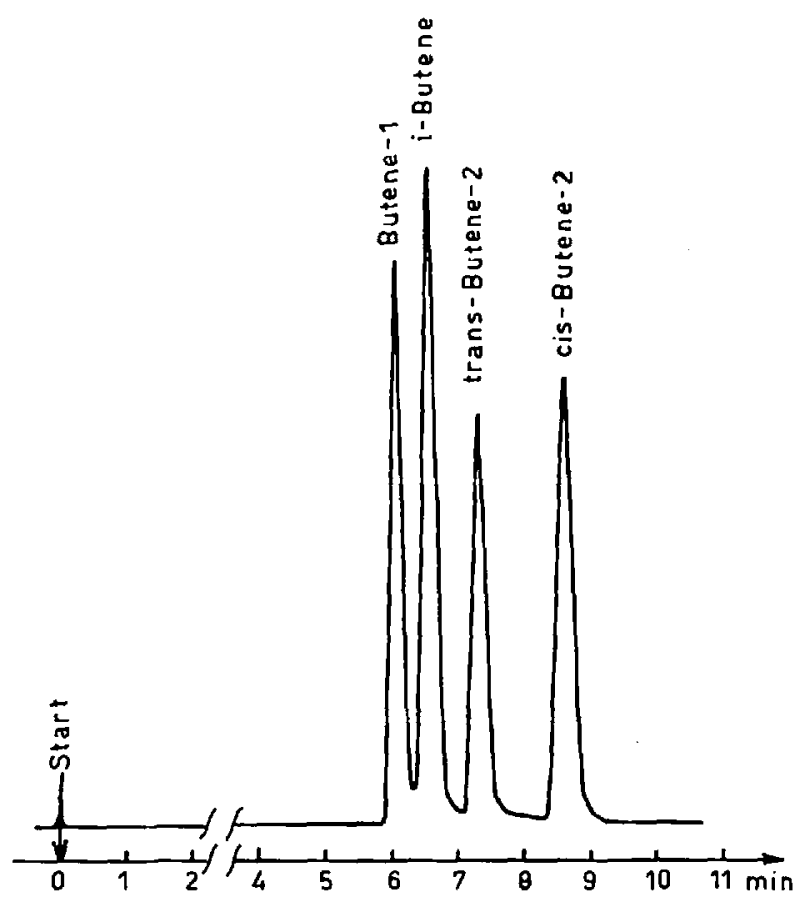

Fig. 1

- Separation of isobutene from butene-1

\section{Literature}

[1] H. Bober: Beckman Application Report No. 1615, Beckman Instruments, Munich 1966.

[2] R. J. Leibrand: Atlas of Gas Analyses by Gas Chromatography, Applications Laboratory Report 1006, HewlettPackard, 1966.

[3] R. Kaiser: Chromatographie in der Gasphase III/1, Bibliographisches Institut, Mannheim 1969

Received: Feb. 27, 1973 Accepted: March 9, 1973

* Sce however separation in packed capillaries: I. Halász, Adv. in Chrom. IV (1968), 248 